\title{
Live political events on Twitter: The case of the 2015 Election Night in Spain
}

Silvia Blas Riesgo| sblasriesgo@gmail.com

Universidad de Navarra

Elsa Moreno Moreno | emoreno@unav.es

Universidad de Navarra

Idoia Portilla | iportilla@unav.es

Universidad de Navarra

Palabras clave

\section{Resumen}

"Twitter"; "Politics"; "Media"; "Citizens";

"Conversation"; "Democracy".

In contemporary democratic society, Twitter can promote a Sumario

1. Introduction.

1.1. Key trends in the political Twittersphere.

1.2. The case and the Spanish context.

2. Method. 2.1. Metrics.

2.2. Data collection.

2.3. Population and sample.

3. Results.

3.1. Activity of actors.

3.2. Actors' Twitter literacy and interaction.

3.3. Actors' visibility

3.4. Limitations of the study.

4. Discussion and conclusions. genuine public debate where the discussion is not limited to established social actors. The goal is studying how media outlets, journalists, political parties, candidates, and citizens behave on Twitter while following the 2015 election night in Spain. A quantitative analysis has been used, specifically focused on the activity generated on Twitter during the period of vote counting ( $n=201,661$ tweets). The data was captured with Tweet Binder, a web tool that allows the live monitoring of the flow of tweets

5. References. related to an event using specific hashtags and keywords. The results reveal that media outlets are at the centre of Twitter activity (representation), but citizens gain high visibility by using humour in the conversation (participation). Founded on the distinctive characteristics of the Spanish context, this article contributes to the understanding of the role of Twitter during a live political event.

\section{Cómo citar este texto:}

Silvia Blas Riesgo, Elsa Moreno Moreno, Idoia Portilla (2019): Live political events on Twitter: The case of the 2015 Election Night in Spain, in Miguel Hernández Communication Journal, nº10 (1), pp. 123 a 145. Universidad Miguel Hernández, UMH (Elche-Alicante). DOI: http://dx.doi.org/10.21134/mhcj.v10i0.281 


\section{Eventos políticos en directo en Twitter: El caso de la noche electoral de 2015 en España}

Silvia Blas Riesgo| sblasriesgo@gmail.com

Universidad de Navarra

Elsa Moreno Moreno | emoreno@unav.es

Universidad de Navarra

Idoia Portilla | iportilla@unav.es

Universidad de Navarra

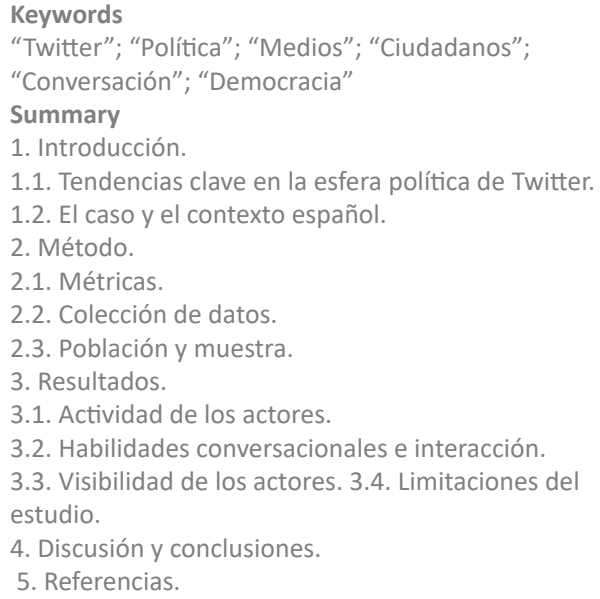

Tweet Binder, que permite el monitoreo en directo del flujo de tweets relacionados con un evento en directo a través del uso de determinados hashtags y palabras clave. Los resultados muestran que los medios están en el centro de la actividad de Twitter (representación), pero los ciudadanos gozan de gran visibilidad a través del humor (participación). Basado en las características del contexto sociopolítico en España, este artículo contribuye a la literatura especializada en Twitter desde la perspectiva de estudio de la función conversacional que desempeña esta plataforma

\section{How to cite this text:}

Silvia Blas Riesgo, Elsa Moreno Moreno, Idoia Portilla (2019): Eventos políticos en directo en Twitter: El caso de la noche electoral de 2015 en España, en Miguel Hernández Communication Journal, n¹0 (1), pp. 123 a 145. Universidad Miguel Hernández, UMH (Elche-Alicante). DOI: http://dx.doi.org/10.21134/mhcj.v10i0.281 


\section{Introduction}

Social media has changed the way citizens, journalists, institutions, and activists communicate about social and political issues (Maireder et al., 2015). As Carpentier (2011) has disclosed, there is an ongoing power struggle between citizens and established social actors in contemporary democratic society. In this context, Twitter appears as a live news media that, technically, allows everybody to participate in the public debate (e.g., Humphreys et al., 2013; Kwak et al., 2010). However, Twitter has often been deemed an 'elite medium' (e.g., Bruns \& Highfield, 2013; Larsson \& Moe, 2011, 2013; Rauchfleisch \& Metag, 2016), although some studies have confirmed its democratic potential for deliberation (e.g., Ausserhofer \& Maireder, 2013; Larsson \& Ihlen, 2015).

By providing interactivity, social media could perform important democratic functions in promoting participatory and transparent governments (Larsson \& Ihlen, 2015), as well as providing a platform for a genuine debate, where the discussion cannot be limited to social elites. Nevertheless, the ideal democratic representation on Twitter has been questioned by Hosch-Dayican et al. who have "raised doubts about the argument that the inclusive character of social media will help bridging the gap between politicians and citizens by allowing for more deliberative democratic processes and, thus, strengthening democratic representation" (2016: 137), an issue also raised by Coleman and Blumler (2009). Larsson and Ihlen agree with this idea, claiming that the "political potential of social media is only partially fulfilled" (2015: 677). Notwithstanding this, it is worthwhile stressing that social media is cooperating with the change of participatory practices and, consequently, the practices of representative democracy (Larsson \& Moe, 2013).

The goal of this article is to describe how media outlets, journalists, political parties, candidates, and citizens behave on Twitter while following the live coverage of a political event: the 2015 election night in Spain. The main purpose of this article is to analyse how the different actor groups participate in the conversation, applying a quantitative analysis to the activity that was generated on Twitter during the period of vote counting ( $\mathrm{n}=201,661$ tweets). Firstly, we employed the web tool Tweet Binder to capture tweets posted through selected hashtags. Secondly, we compared the type of tweets sent by different actors. Thirdly, we observed the use of innate resources by each user to discern whether there are differences in the degree of their literacy of the platform, and, lastly, we identified their visibility in the conversation.

According to the theoretical approach based on the normative criterion of which actor groups participate in the Twittersphere (e.g., Larsson \& Moe, 2013 in line with the public spheres theories established by Ferree et al., 2002), we aim to answer the following main research question: Who dominates the conversation activity on Twitter during the 2015 election night in Spain? The established social actors, or anonymous citizenry? We focus on Twitter interactivity and, particularly, on how this platform provides a wide selection of conversational features (e.g., Hosch-Dayican et al., 2016; Kwak et al., 2010; Limia, López, \& Toural, 2016; Maireder et al., 2015). While the Internet comprises multisector online public spheres (Dahlgren, 2005), and even a contemporary global public sphere (Castells, 2008), we understand the Twittersphere as one of the virtual spaces where people from diverse cultural backgrounds interact to exchange information, ideas, and opinions (Larsson \& Ihlen, 2015; Maireder et al., 2015).

The results show that media outlets are at the centre of Twitter activity during the live coverage of a political event, which confirms the theories related to representation. Otherwise, citizens 
gain high visibility by using humour in the conversation, linking to participation theories. However, consolidating Twitter literacy remains a challenge for fostering a genuine dialogue.

\subsection{Key trends in the political Twittersphere}

Twitter has a particular capacity to allow everybody to be involved in the online political discourse due to its open, horizontal, and broadly-networked architecture (Park, 2013). Therefore, this social network could help to raise social inclusiveness in terms of participation (Hosch-Dayican et al., 2016), but the conversation is opposed to the traditional politics that has long been associated with high culture (Jenkins et al., 2014). Although there is a dearth of transnational comparative studies on the political Twittersphere (Bruns \& Stieglitz, 2013; Larsson \& Moe, 2014), insights may be summarised according to, firstly, the characteristics of the activity and secondly, the specific behaviour of the actor groups.

In the field of politics the clearest interactions on Twitter occur between citizens and politicians, and journalists and experts (Ausserhofer \& Maireder, 2013). This pattern helps to understand that political events, mediated or not, increase Twitter activity in many countries (e.g., Bruns \& Highfield, 2013; Jungherr, 2014; Jungherr, Schoen, \& Jürgens, 2015; Larsson \& Moe, 2011, 2013; Vaccari, Chadwick, \& O'Loughlin, 2015). Nonetheless, previous works have shown that high-end users provide the majority of the comments (Larsson \& Moe, 2011), specifically those users with prominent positions in media or politics (e.g., Bruns \& Highfield, 2013; Rauchfleisch \& Metag, 2016). Consequently, Twitter is often seen as an "elite medium of sorts" (Larsson \& Moe, 2013).

Regarding the behaviour of the actor groups, recent contributions have confirmed how politicians' tweeting action is affected by conditions implanted in different political and media systems (e.g., Graham, Jackson, \& Broersma, 2016; Larsson \& Moe, 2014; Rauchfleisch \& Metag, 2016). Various factors, such as electoral system, political culture, or democratic status of a country, are implicated in this process. Moreover, the Twittersphere evolves towards a more communicative channel for politicians (Larsson \& Ihlen, 2015). This is in contrast with initial findings which have presented this social network as a unidirectional form of communication (e.g., Broersma \& Graham, 2012; Graham et al., 2013; Honeycutt \& Herring, 2009; Kwak et al., 2010; Larsson \& Moe, 2011). We can find some examples of this behaviour in the Austrian Twittersphere, where political core users interact with each other intensely (Ausserhofer \& Maireder, 2013), in the activity of Dutch politicians (Graham et al., 2016), or in that of Norwegian politicians (Larsson \& Ihlen, 2015).

Furthermore, some scholars have recently indicated a certain change to a "deideologisation" of the platform in Nordic countries (Larsson \& Ihlen, 2015: 675), while earlier research had reported a majority of left-wing activity on Twitter (e.g., Ausserhofer \& Maireder, 2013), and an overrepresentation of small political parties (e.g., Ausserhofer \& Maireder, 2013; Bruns \& Highfield, 2013; Jungherr et al., 2015; Larsson \& Moe, 2013). Scholars have also proved that the citizenry is indeed participating in political discussions via Twitter. In the Austrian Twittersphere, about half of users were people without a professional political affiliation (Ausserhofer \& Maireder, 2013); at the local elections in Belgium during the 2012 election day, $74 \%$ of users were citizens (D'heer \& Verdegem, 2014); and in the 2011 Danish election campaign, these actors were among those who tweeted most actively about the election (Larsson \& Moe, 2013). A similar pattern was observed in the 2012 Dutch election campaign (Hosch-Dayican et al., 2016) and the 2011 gubernatorial elections in the United States (Bekafigo \& McBride, 2013). 
According to Larsson and Moe, individual users or civil society groups can constitute a high percentage of so-called "influential users"; thus, political communication in this case "transgresses the idea of representation, and includes popular participation" (2013: 83).

Likewise, and taking into account that commenting on politics now involves second screen use, research also reflects that Twitter has become a digital backchannel for public reactions to political events (e.g., Giglietto \& Selva, 2014; Gil de Zúñiga, García-Perdomo, \& McGregor, 2015; Jungherr, 2014). Additionally, most tweets commenting on these events did so ironically - an indicator that Papacharissi and De Fatima Oliveira (2012) have termed as 'affective news'. Finally, journalists have been high-end users of the platform, for instance, during the 2011 Danish election campaign (Larsson \& Moe, 2013) or in the everyday political discussions in Sweden and Norway (Larsson, 2014). However, compared with other actor groups, journalists' Twitter activity has reduced, in, for example, such cases as the 2012 Dutch parliamentary election campaign (Hosch-Dayican et al., 2016). Journalists could be also characterised as "elite networks" (Ausserhofer \& Maireder, 2013) because they are often following politicians (Rauchfleisch \& Metag, 2016) and are frequently addressed by politicians (Graham et al., 2013).

Regarding the democratizing potential of online news sources, Lecheler and Kruikemeier have recognised that "journalists still gravitate toward elite sources, and do not show a decrease in traditional news sourcing techniques" (2016: 167). Therefore, journalists continue to select credible sources (e.g., Moon \& Hadley, 2014; Wallsten, 2015), and this has a direct implication for the political agenda (e.g., Broersma \& Graham, 2012; Parmelee, 2014). While social media constitutes a favourable environment for political participation (Limia et al., 2016) Karlsson et al. assert that the "revolution that wasn't because participatory journalism seems to have decreasing value to producers and little appeal to users" (2015: 295). In fact, several studies have shown that media outlets tend to develop very limited opportunities for citizen participation (e.g., Messner, Linke, \& Eford, 2011; Paulussen et al., 2007). Hence, promoting a more open journalism culture (Deuze, 2003) is a real challenge.

\subsection{The case and the Spanish context}

A The political system of the Spanish state has been, since 1978, a parliamentary monarchy. On 20 December 2015, 36,510,952 inhabitants could vote. National elections were held to renew the Congress (350 elected politicians) and the Senate (208 elected politicians). The Spanish political system is described as party-centred rather than candidate-centred. Eight political formations met in all electoral districts: Partido Popular (PP), Partido Socialista Obrero Español (PSOE), Ciudadanos, Podemos, Partido Animalista contra el Maltrato Animal (PACMA), Recortes CeroGrupo Verde, Unidad Popular (UP) (including Izquierda Unida and Unidad Popular en Común before Ahora en Común), and Unión Progreso y Democracia (UPyD).

The 2015 General Election in Spain was an historic occasion due to the emergence of two new political parties: Podemos (founded in January 2014) and Ciudadanos (established in 2005 in the Spanish region of Cataluña but with increasing relevance in the rest of the country). These new political parties experienced rapid growth and broke the bipartisanship between Partido Popular (PP), or the centre right, and Partido Socialista Obrero Español (PSOE), or the centre left, which had characterised the Spanish democracy until that moment. Therefore, the interest in who was going to win the 2015 general election boosted among the citizenry. 


\section{Method}

Twitter allows users to post short textual messages, or tweets, and can be linked to multimedia content (hyperlinks). Tweets can include hashtags, where the \# character, together with a word or phrase, connect the tweet to an event or discussion.

According to the main research question presented in the introduction to this article, we posit the following research sub-questions to deepen the analysis of the activity generated on Twitter during the 2015 election night in Spain. 1) Were all the actors equally active on Twitter while following the live coverage of a political event? 2) To what extent did each type of actor use Twitter's innate resources? 3) Did all the actors have the same level of visibility in the conversation?

These sub-questions require different metrics to measure three elements: (1) activity, (2) use of innate resources, and (3) visibility. We explain the metrics used in the following section.

\subsection{Metrics}

Measuring user activity necessitates the count of the tweets sent by each user (Bruns \& Stieglitz, 2013). These can be broken down into original tweets or singletons and @mentions. Following the basic typology proposed by Kwak et al. (2010), a singleton is a statement from a specific user, without the@ sign, while the mention includes the@ sign followed by a user ID. Thus, to address the first research sub-question, we count the volume of tweets of each type by actor. Twitter is optimised to allow for conversation among its users. We can find replies and retweets.

A reply uses the@ sign followed by a user ID and a retweet is marked with RT (Kwak et al., 2010). Replies allow the user to address other users (Honeycutt \& Herring, 2009). By retweeting messages, "users indicate that they deem the message important" (Jungherr, 2014: 251). Furthermore, tweets can include hyperlinks, mostly linking to websites, pictures, graphics, and videos for providing a greater understanding of the issues covered. Replies and hyperlinks are metrics already considered by Bruns and Stieglitz (2013). We added retweets as another innate resource and observed to what extent each type of actor employs them compared to other actors, so as to answer the second research sub-question. A high rate of use of all these innate resources will imply high Twitter literacy.

Regarding the third research sub-question, visibility is measured by retweets and @mentions received (Bruns \& Stieglitz, 2013; Jungherr, 2014; Larsson \& Moe, 2011). A higher number of retweets indicates that the retweeted accounts have a higher ability to spread their message around the Twittersphere, surpassing the limitation of the number of followers. The number of mentions reveals the amount of times a specific user has been directly consulted. It can be used as a relevant measure because it reveals the ability of a user to establish dialogue with others. Therefore, in this research, we analyse the top ten most retweeted accounts, the top ten most mentioned accounts, the most popular accounts and, finally, the accounts with the highest potential impact in the conversation.

\subsection{Data collection}

Twitter's data collection is based on news event hashtags, which is a common way among scholars to address Twitter activity during election times (e.g., Bruns \& Burgess, 2011; Bruns \& Highfield, 2013; D’heer \& Verdegem, 2014; Hosch-Dayican et al., 2016; Jungherr, 2014; Jungherr et al., 2015; Larsson \& Moe, 2011, 2013, 2014; Vaccari et al., 2015). As Jungherr explains, "using 
hashtags as a discriminatory criterion allows filtering messages that users posted with the clear intention of contributing to the political discourse" (2014: 244). The main disadvantage of the focus on hashtags is that it might potentially underestimate the total volume of activity around the topic. However, this is the best approach to prevent the dilution of data in the noise generated by the high number of tweets sent per minute.

There is a range of tools to collect Twitter data and monitor Twitter activity, such as yourTwapperKeeper (e.g., Bruns \& Highfield, 2013; Larsson, 2014; Larsson \& Ihlen, 2015; Larsson \& Moe, 2013, 2014). As we said before, we use the tool Tweet Binder. An important advantage of this tool is that it obtains the data from the so-called firehose level of access to the Twitter Application Programming Interface (API), so it is possible to obtain the complete dataset of tweets for a selection of hashtags. Furthermore, this paid web tool is appropriate to this case because it allows the live monitoring of an event and the storing of tweets in folders called 'binders', grouping tweets with a specific term or by a specific actor.

\subsection{Population and sample}

The population of the study is made up of all the tweets about the electoral results during the counting of votes. The Spanish polling stations closed at 8.00 p.m., local time. The counting of votes started after it, opening the election night and the data collection.

The selection of tweets related to the election night took into account 21 different hashtags (see Table 1). The three official ones (\#EleccionesGenerales2015, \#20D, and \#Eleciones20D) were used throughout the entire campaign. In addition, some media outlets and political parties created their own hashtags that could be discovered using the free tool TrendsMap (http:// trendsmap.com/) during the election day.

Table 1. Hashtags tracked while following the 2015 election night in Spain on Twitter.

\begin{tabular}{|l|l|l|}
\hline Hashtag & Nature & Source \\
\hline \#EleccionesGenerales2015 & Official & Home Office \\
\hline \#20D & Official & Home Office \\
\hline \#Elecciones20D & Official & Home Office \\
\hline \#PartidoPopular & Political party & Partido Popular \\
\hline \#Psoe & Political party & Partido Socialista Obrero Español \\
\hline \#PODEMOS & Political party & Podemos \\
\hline \#Ciudadanos & Political party & Ciudadanos \\
\hline \#ELPAIS20D & Press & El País \\
\hline \#MiVotoCuenta & Online press & El Español \\
\hline \#ABC20D & Press & ABC \\
\hline \#EleccionesLV & Press & La Vanguardia \\
\hline \#L6elecciones & Television & laSexta \\
\hline \#eleccionesA3 & Television & Antena 3 \\
\hline \#20DTelecinco & Television & Telecinco \\
\hline \#20DenCuatro & Television & Cuatro \\
\hline
\end{tabular}




\begin{tabular}{|l|l|l|}
\hline \#20DenCOPE & Radio & Cope \\
\hline \#20dEnLaSER & Radio & Cadena SER \\
\hline \#EleccionesRTVE & $\begin{array}{l}\text { Television / } \\
\text { Radio }\end{array}$ & RTVE \\
\hline \#OndaCero20D & Radio & Onda Cero \\
\hline \#esRadio20D & Radio & esRadio \\
\hline \#CarneCruda20D & Radio & Carne Cruda \\
\hline
\end{tabular}

The final sample reached 201,661 tweets. The first tweet was captured at 9.36 p.m. (20 December 2015) and the last one at 00.20 a.m. (21 December 2015), when the count had finished. Tweet Binder facilitates the tracking of accounts by creating a folder (binder) for each account. In this research, we were interested in the activity of different users (actors) as the general public, political institutions, media outlets, and journalists. The accounts were selected in advance as detailed below.

We selected 13 accounts related to the Home Office and political users (see Table 2), 21 media accounts (see Table 3), and 20 belonging to journalists (see Table 4).

Table 2. Public institutions and political accounts whose activity was collected while following the 2015 election night in Spain on Twitter.

\begin{tabular}{|l|l|l|}
\hline Name & Twitter account & Nature \\
\hline $\begin{array}{l}\text { Ministerio del Interior (Home } \\
\text { Office) }\end{array}$ & $@$ interiorgob & Public Institution \\
\hline Mariano Rajoy & $@$ marianorajoy & Partido Popular candidate \\
\hline Pedro Sánchez & $\begin{array}{l}\text { @sanchezcas- } \\
\text { tejon }\end{array}$ & PSOE candidate \\
\hline Pablo Iglesias & $@$ pablo_iglesias & Podemos candidate \\
\hline Albert Rivera & $@$ albert_rivera & Ciudadanos candidate \\
\hline Alberto Garzón & $@$ agarzon & Unidad Popular candidate \\
\hline Andrés Herzog & $@$ herzogoff & UPyD candidate \\
\hline Partido Popular & $@$ ppopular & Political party \\
\hline PSOE & $@$ psoe & Political party \\
\hline Podemos & $\begin{array}{l}@ \text { ahorapode- } \\
\text { mos }\end{array}$ & Political party \\
\hline Ciudadanos & $@$ ciudadanoscs & Political party \\
\hline Unidad Popular & $@$ iunida & Political party \\
\hline UPyD & $@$ upyd & Political party \\
\hline & &
\end{tabular}

Regarding the media outlets, we selected the five main printed newspapers which cover national political affairs, as well as the free newspaper 20 minutos. The five generalist television channels and the four main talk radio networks (all of them with national coverage) were also included. In addition, due to their extensive activity on Twitter, four digital newspapers (El Confidencial, eldiarioes, El Español, and Público) as well as the radio EsRadio and the program Carne Cruda (related to the digital native media eldiario.es) were followed as well (see Table 3). 
Table 3. Media outlets' accounts whose activity was collected while following the 2015 election night in Spain on Twitter.

\begin{tabular}{|c|c|c|}
\hline Name of the media & Twitter account & Nature \\
\hline 20 Minutos & @20m & Press \\
\hline $\mathrm{ABC}$ & @abc_es & Press \\
\hline El Confidencial & @ECElecciones & Press \\
\hline El Español & @elespanolcom & Press \\
\hline El Mundo & (a)elmundoes & Press \\
\hline El País & (a)el_pais & Press \\
\hline Eldiario.es & (a)eldiarioes & Press \\
\hline La Razón & (a)larazon_es & Press \\
\hline La Vanguardia & @LaVanguardia & Press \\
\hline Público & (apublico_es & Press \\
\hline Antena 3 & @antena3com & Television \\
\hline Cuatro & @ cuatro & Television \\
\hline laSexta & @laSextaTV & Television \\
\hline Telecinco & (a)telecincoes & Television \\
\hline TVE & @LLa1_tve & Television \\
\hline Cadena SER & @LLa_SER & Radio \\
\hline Cope & @-cope_es & Radio \\
\hline Eldiario.es & $\begin{array}{l}\text { @ carnecruda- } \\
\text { radio }\end{array}$ & Radio \\
\hline Es.Radio & (@esRadio & Radio \\
\hline Onda Cero & @OndaCero_es & Radio \\
\hline RNE & (a)rne & Radio \\
\hline
\end{tabular}

Journalists were chosen according to a report published by Burson-Marsteller (Europa Press, 2015) that discloses the 20 most influential journalists on Twitter for Spanish political leaders (see Table 4).

Table 4. The 20 most influential journalists on Twitter whose activity was collected while following the 2015 election night in Spain on Twitter.

\begin{tabular}{|l|l|}
\hline Name of the journalist & Twitter account \\
\hline Ana Pastor & $@$ _anapastor_ \\
\hline Antoni Gutiérrez & $@$ antonigr \\
\hline Arsenio Escolar & @arsenioescolar \\
\hline Casimiro García-Abadillo & $\begin{array}{l}\text { @garcia_aba- } \\
\text { dillo }\end{array}$ \\
\hline
\end{tabular}




\begin{tabular}{|l|l|}
\hline Carlos E. Cué & $@$ carlosecue \\
\hline Carmen del Riego & $\begin{array}{l}\text { @Carmendel- } \\
\text { Riego }\end{array}$ \\
\hline Esther Palomera & $\begin{array}{l}\text { @estherpalo- } \\
\text { mera }\end{array}$ \\
\hline Fernando Garea & $@$ Fgarea \\
\hline Ignacio Escolar & $@$ iescolar \\
\hline Jesús Maraña & $@$ jesusmarana \\
\hline Jordi Évole & $@$ jordievole \\
\hline Juan Ramón Lucas & $@$ JuanraLucas \\
\hline Julia Otero & $@$ julia_otero \\
\hline María Rey & $@$ maria_rey \\
\hline Melchor Miralles & $\begin{array}{l}\text { @melchormi- } \\
\text { ralles }\end{array}$ \\
\hline Pedro J. Ramírez & $\begin{array}{l}\text { @pedroj_rami- } \\
\text { rez }\end{array}$ \\
\hline Pepa Bueno & $@$ PepaBueno \\
\hline Sonsoles Ónega & $@$ sonsolesonega \\
\hline Susana Griso & $@$ susannagriso \\
\hline Vicente Vallés & $\begin{array}{l}\text { TVicenteValles- } \\
\text { TV }\end{array}$ \\
\hline
\end{tabular}

\section{Results}

As the selection of data was made by hashtags, the first step was analysing their use and identifying the contributors. As we can see in Figure 1, the most-used hashtag was \#L6elecciones, belonging to the television channel laSexta, which was broadcasting the political talk show Debate Al Rojo Vivo during election night.

The second and third most-used hashtags were the official ones, \#eleccionesgenerales2015 and \#20d. In addition, three other hashtags created by media outlets were ranked into the ten most-used: \#mivotocuenta (belonging to the online press media El Españo), \#eleccionesa3 (launched by the television station Antena 3), and \#CarneCruda20D (associated with the media eldiario.es). The last four belonged to the main political parties that participated in the elections: \#PODEMOS, \#Psoe, \#ciudadanos, and \#PartidoPopular.

Therefore, four of ten top hashtags are linked to media and another four to political parties, but this finding does not imply that these groups were the main actors in the activity of Twittersphere, only that their tags were relevant. 
Figure 1. Top ten most-used hashtags. Source. Tweet Binder report.

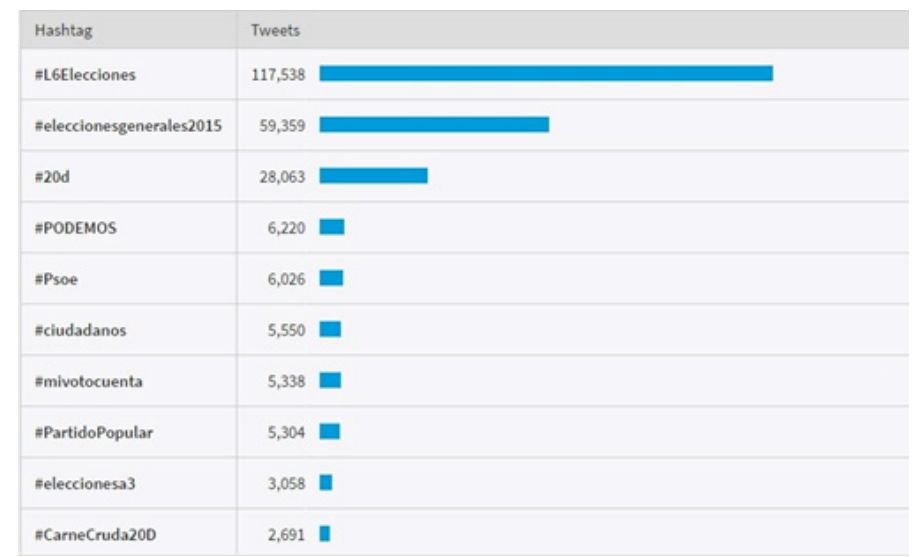

During the period of vote counting, 104,219 contributors sent 201,661 messages on Twitter. By type of messages, there were 47,928 singletons $(23.76 \%), 152,425$ retweets $(75.58 \%)$, and 1,308 replies $(0.65 \%)$, as we can observed in Figure 2. Hence, the majority of the tweets sent were unidirectional messages, rather than conversations. In consequence, it may be said that there is not a clear interaction among actors.

Figure 2. Distribution of tweets by type and time. Source. Tweet Binder report.

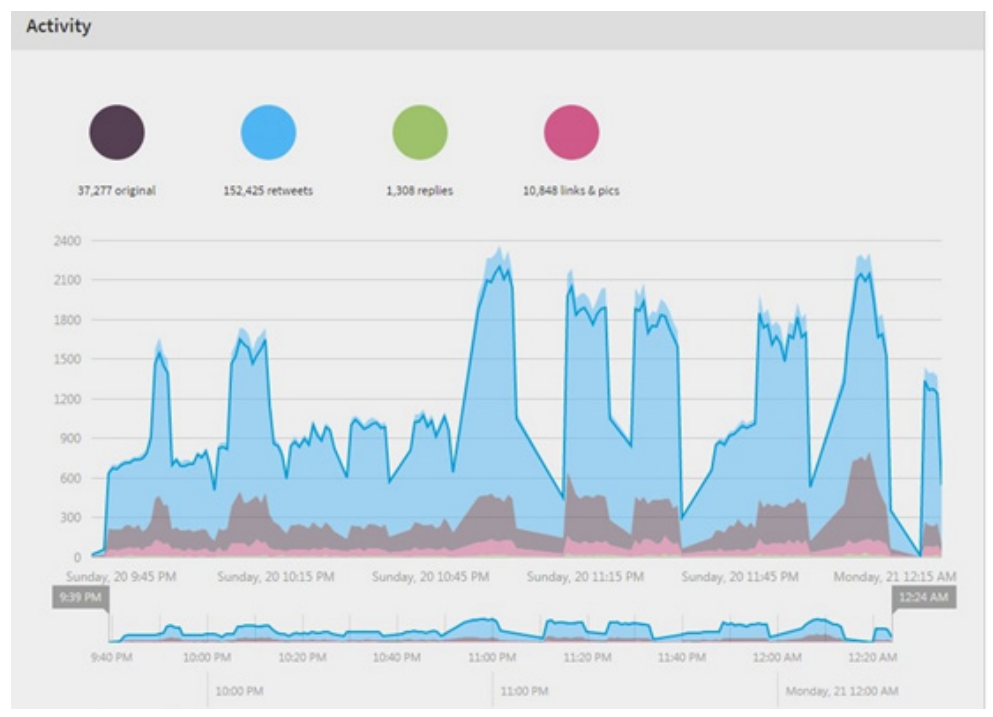

Each user sent, on average, 1.93 messages while following the vote counting. Most of the users sent only one tweet $(65.15 \%)$, followed by the ones that sent only two $(17.34 \%)$. Thus, it seems that many users sent a message without the intention of starting a conversation.

The 104,219 contributors of the sample each had 1,782 followers on average, and 59.07\% of the tweets came from contributors with only 50-500 followers. This means that the most frequent 
contributors were not relevant social actors or "elite actors" of the political Twittersphere. On the other hand, 2,780 contributors (responsible for 2.66\% of the sample of tweets) had more than 5,000 followers.

Concretely, media outlets fall into this second category because this actor group had, on average, 914,526 followers. Nevertheless, journalists had 417,641 followers on average, but there are significant differences among them. Ana Pastor, for example, the most-followed journalist in the sample, had 1,576,502 followers, and Antoni Gutiérrez, the least-followed journalist of those selected, had only 18,309. Anyway, the media actors are in the group responsible of less than $3 \%$ of the sample of tweets.

Political parties also belonged to the most-followed groups, but to a lesser extent than media outlets. On average, they had 445,327 followers. Podemos is at the top with 860,723 followers, and UPyD closes the ranking with 185,991 followers. Among the political candidates, Pablo Iglesias (Podemos candidate) had the highest amount of followers, 1,567,344; the second most followed is Mariano Rajoy (Partido Popular candidate), with 1,151,678 followers; and the one with the least amount of followers is Andrés Herzog (UPyD candidate), with 16,800. As the political parties have more than 5,000 followers, they are in the group providing less than $3 \%$ of the sample of tweets.

\subsection{Activity of actors}

The analysis of the top ten contributors confirms previous results that those who sent the highest number of tweets and retweets were non-established social actors (e.g., Ausserhofer \& Maireder, 2013; D’heer \& Verdegem, 2014; Larsson \& Moe, 2013). The main contributors were people outside the media or politics. However, among the ten most active accounts sending original messages, there were four noteworthy media accounts: @Gogglenewsspain (which works as a news aggregator), @laopinionspain (a native Twitter news media outlet about politics), @DiarioHuelva (belonging to a regional newspaper), and @la_informacion (online press media).

The media outlets selected (see Table 3) sent on average 19.28 messages while covering the election night. Regarding the journalists (see Table 4), only six of the 20 journalists considered participated in the conversation. This lack of activity could be due to the fact that election night is a special news evening and the journalism routines are more demanding than on an average day.

Concerning the political parties group, there were two highly active parties: PSOE and Podemos, with 46 and 16 tweets respectively. Both of these parties are left-wing. The rest of the political parties tweeted between three and five times. Meanwhile, no activity of the political candidates was captured - probably because they had to attend obligatory public events, such as speeches or interviews. Other explanation of the lack of activity of candidates is the existence a complementary strategy on Twitter between the profiles of the candidates and their parties (Alonso-Muñoz \& Casero-Ripollés, 2018).

Lastly, the official Twitter account of the Home Office sent three messages during the vote counting period. As a result, we can say that this actor was not predominant as a contributor in the political Twittersphere. However, its hashtag was very relevant, as we saw previously, what demonstrates its relevance as a source of information about the evolution of electoral results during the live news coverage. 


\subsection{Actors' Twitter literacy and interaction}

Links or pictures were included in only $5.38 \%$ of our sample. Among the top ten photographers, there were seven accounts that were related to the news industry. Those were: @googlenewspain (a news aggregator), @ColpisaNoticias (a news agency), @diariovasco (a regional newspaper), @ecd_(ElConfidencial, an online newspaper with an account for the elections), @periodistadigit (an online newspaper), @elespanolcom (an online newspaper), and @DiarioSur (a regional newspaper). The other three accounts were@TrenTopicsEsp (a kind of message aggregator related to the trending topics in Spain),@PruebasBizarras, and@garlic1975, both accounts outside the established social actors. Therefore, media seems to be the more Twitter-literate actors.

Specifically, media outlets sent on average 11.78 links and pictures while covering the election night. This average, when divided by the average of tweets sent by media, tells that $61.09 \%$ of their messages would have a link or a picture. Journalists either sent only one link or picture, or none. Among the political parties, only PSOE had six shared links or pictures, and PP and UPyD had one shared link or picture. Finally, the Home Office shared a link in each tweet sent, so all of them included this feature.

Other innate resource is the retweet. In this case, media outlets sent, on average, 4.78 retweets. When we divided this average by the average of tweets sent by media, we observed that $24.79 \%$ of these messages included retweets. Concerning journalists, only three retweeted a message. Journalists did not really participate in the conversation, either by tweets or retweets, with the exception of Ana Pastor (journalist from laSexta television). With respect to the political parties, the main retweeter was PSOE, which sent 35 retweets. Next, the left-wing party Podemos shared 16 retweets. Lastly, PP, UPyD, and Ciudadanos sent less than four retweets each. The Home Office, as the official news source of the political event, did not retweet any message.

The null interaction of the Home Office is a logical finding because this actor is the main source of information during the election night; it is not a spreader. But the low number of links, pictures or retweets from media and political parties is striking. It could imply a low Twitterliteracy level or also a low interest in promoting the interaction with other established social actors or citizens.

\subsection{Actors' Twitter literacy and interaction}

Among the most-retweeted users, only four were established social actors: @PartidoPACMA (political party),@Pablo_Iglesias (Podemos candidate), @CiudadanosCs (political party), and @ A3Noticias (news media programme of Antena 3 television). The other six were citizens, whose accounts had in common that the messages they sent were characterised by humour, some kind of irony, or even sarcasm. Moreover, they often linked pictures or memes. Hence, people like to spread more ironic and comic tweets associated with non-traditional politics than other types of messages.

Regarding the number of mentions, political parties were at the top of the list. Six of ten of the most-mentioned accounts belong to political parties: @ahorapodemos, @CiudadanosCs, @ PSOE,@Esquerra_ERC,@PartidoPACMA, and@EnComu_Podem. There was also one of the political candidates: Pablo Iglesias (@pablo_iglesias) of the left-wing Podemos party. This result confirms the relevance of these actors at an electoral event, what seems foreseeable. 
Among journalists, Ana Pastor (@_anapastor_) is in the top ten most-mentioned accounts, what can be related to her high number of followers, as we saw before. The political talk show belonging to laSexta television, called @DebatAlRojoVivo, is the only media outlet in this ranking. Its hashtag was also one at the top ten ranking.

The account of the Home Office (@interiorgob) is placed on the last position of the top ten list of mentions. Thus, it is a significant protagonist but not the first one, although it is the main source of information and data during the analysed event.

None of the media outlets accounts listed in the method section of this paper was among the most-mentioned. One reason could be that the citizens were more interested in the interaction with the political actors during election night, rather than with the media. Nevertheless, the fact that those accounts received direct interpellations does not mean that they answered to them.

\subsection{Limitations of the study}

As we said before, as the sample was collected by hashtags, it could be possible that tweets related to the 2015 general election that did not include hashtags were not captured. However, without the hashtag, it is hard to discern between messages that are really part of the conversation and those that are noise.

Another limitation was selection of media outlets. Originally, only the mainstream media and the most active media outlets on Twitter were considered. However, as the results showed, there were other media contributors not included in the sample for this research.

The paid web tool Tweet Binder has some limitations, too. One is the fact that it does not distinguish between pictures and links, so we cannot determine the specific amount of each of them. Also, it does not specify how many replies each account sent, because it only offers an overview of the total number of replies in the conversation.

\section{Discussion and conclusions}

This research provides insights into which actor groups dominated the conversation activity on Twitter during 2015 election night in Spain - whether the established social actors (media outlets, journalists, political parties, and candidates), or anonymous citizenry were more active. According to the theoretical approach based on the normative criterion of which actor groups participate in the Twittersphere (e.g., Larsson \& Moe, 2013 in line with the public spheres theories established by Ferree et al., 2002), this article contributes to literature evaluating the inclusive character of social media during a live political event. Specifically, this research has revealed three main findings in consonance with hashtag activity and the specific behaviour of the actor groups.

The Twittersphere analysed in this research was mainly operated as a mediated space for political representation, despite the democratic potential that social media has for two-way communication (e.g., Ausserhofer \& Maireder, 2013; Bekafigo \& McBride, 2013; Graham et al., 2013; Larsson \& Ihlen, 2015). In contrast with preceding studies, where Twitter was 
used for political reflection (e.g., Tumasjan et al., 2010), our results highlight retweeting. The number of retweets $(75.58 \%$ ) was very high compared to previous works (e.g., Ausserhofer \& Maireder, 2013; Bruns \& Highfield, 2013; Jungherr, 2014; Larsson \& Moe, 2011, 2013). Thus, it would be worthwhile to examine the echo chamber phenomenon and opinion leadership on Spanish political Twittersphere in future studies as is the case in other contexts (e.g. Dubois \& Blank, 2018; Esteve \& Borge, 2018; Guo, Rohde, \& Wu, 2018). Even today, the users' partisan preference (Baviera, 2018).

Media outlets were found to be the dominating actor group sending original tweets or singletons, while citizens were more involved in retweeting (e.g., Hosch-Dayican et al., 2016; Larsson \& Moe, 2013). That confirms the broadcast notion. Moreover, the finding that the most-used hashtag was \#L6elecciones suggests that journalistic mediation continues to lead the flow of political communication on Twitter (Vaccari \& Valeriani, 2015), although people serve as catalysts in the distribution of messages (Chadwick, 2013). There is a low interaction activity because $65.15 \%$ of the contributors in the sample only sent one message, as shown in prior studies (e.g., D’heer \& Verdegem, 2014; Tumasjan et al., 2010; Vaccari \& Valeriani, 2015). A question that requires further study.

The Spanish case may be also contemplated as a political participation sphere, because the top ten contributors' accounts belonged to the citizenry (popular inclusion). This finding supports other studies (e.g., Ausserhofer \& Maireder, 2013; D’heer \& Verdegem, 2014; Larsson \& Moe, 2013) and confirms that "anonymous Twitter enthusiasts can indeed make their voice heard" (Larsson \& Moe, 2014: 10). Therefore, there is further evidence that during a political event, social elites are not the only commentators that matter (e.g., Bekafigo \& McBride, 2013; Freelon \& Karpf, 2015; Hosch-Dayican et al., 2016).

Actually, citizens are more likely to respond to messages than other actor groups, such as in the example of local elections in Belgium (D'heer \& Verdegem, 2014). This issue is relevant for future studies because our research indicates that political actors forget Twitter's deliberative potential compared with other contexts (e.g., Ausserhofer \& Maireder, 2013; Larsson \& Ihlen, 2015). Nonetheless, it is important to highlight the activity of the emerging left-wing political party, Podemos, and the established social-democrat political party, PSOE, to lead the current left discourse among the electorate. Journalists' accounts also reflect a forgetfulness of Twitter's potential for deliberation.

The second conclusion suggests that all actor groups were not highly Twitter-literate. For instance, only $5.38 \%$ of the total of messages captured had pictures or links. As promoters of Twitter activity, media outlets employed more of these conversational skills $(61.09 \%$ of their messages) than other uses. However, the Home Office shared a link in each tweet sent (three). Another question that requires further study is to what extent those links belong to their own websites, or whether they contain another kind of content. Regarding the retweets, media outlets, political parties PSOE and Podemos, and the journalist Ana Pastor concretely participated in that way. Nevertheless, Dahlgren asserts that "online discussions do not always follow the high ideals set for deliberative democracy" (2005: 156), at least for the present. 
Lastly, the third conclusion corroborates that the citizenry gain high visibility using the humour in the conversation. Indeed, six of the ten most-retweeted accounts belonged to the public. Precisely, Jenkins, Ford, and Green (2013) argue that humour is one of the key qualities that make messages 'spreadable' online, and scholars back this idea (e.g., Jungherr, 2014; Molyneux, 2015). There is an empowerment by citizens, and this trend reflects the change in participatory practices (Larsson \& Moe, 2013).

Furthermore, our research shows that the Spanish Twittersphere is not discovered as a "deideologisation" space, in contrast to Nordic countries (Larsson \& Ihlen, 2015). The fact that Pablo Iglesias was one of the most-retweeted users reinforces the notion that progressive parties tend to have wider potential impact on Twitter (e.g., Ausserhofer \& Maireder, 2013). Podemos and Ciudadanos were the most-mentioned actors because these new parties were interpreted as an endeavour to open up the political representation towards the left and the centre-right electorate, respectively. Additionally, the journalist Ana Pastor stands out by her visibility thanks to her presence in LaSexta television.

In summary, according to Larsson and Moe (2013), it may be concluded that the Twittersphere during the 2015 election night in Spain transgresses the idea of representation and includes popular participation. Citizens are clearly interested in participating in politics via Twitter, and live political events have achieved a key relevance in the "hybrid media systems" (Chadwick, 2013). Nevertheless, consolidating Twitter literacy remains a challenge for fostering a genuine dialogue. Therefore, it may be appropriate to suggest that established Spanish social actors could embrace the interactivity in order to promote dialogue about political processes.

\section{References}

Alonso-Muñoz, L., \& Casero-Ripollés, A. (2018). Political agenda on Twitter during the 2016 Spanish elections: issues, strategies, and users' responses. Communication \& Society, 31(3), 7-25. DOI: https://doi.org/10.15581/003.31.3.7-25

Ausserhofer, J., \& Maireder, A. (2013). National Politics on Twitter. Structures and topics of a networked public sphere. Information, Communication \& Society, 16(3), 291-314. DOI: https://doi. org/10.1080/1369118X.2012.756050

Baviera, Tomás (2018). Influence in the political Twitter sphere: Authority and retransmission in the 2015 and 2016 Spanish General Elections. European Journal of Communication, 33(3), 321-337. DOI: https://doi.org/10.1177/0267323118763910

Bekafigo, M., \& McBride, A. (2013). Who tweets about politics? Political participation of Twitter users during the 2011 gubernatorial elections. Social Science Computer Review, 31(5), 625-643. DOI: https://doi.org/10.1177/0894439313490405 
Broersma, M., \& Graham, T. (2012). Social media as beat: tweets as a news source during the 2010 British and Dutch elections. Journalism Practice, 6(3), 403-419. DOI: https://doi.org/10.1080/ 17512786.2012 .663626

Bruns, A., \& Burgess, J. E. (2011). \#Ausvotes: How twitter covered the 2010 Australian federal election. Communication, Politics \& Culture, 44(2), 37-56.

Bruns, A., \& Highfield, T. (2013). Political Networks on Twitter: Tweeting the Queensland state election. Information, Communication \& Society, 16(5), 667-691. DOI: https://doi.org/10.1080/13691 18X.2013.782328

Bruns, A., \& Stieglitz, S. (2013). Towards More Systematic Twitter Analysis: Metrics for Tweeting Activities. International Journal of Social Research Methodology, 16(2), 91-108. DOI: $\underline{10.1080 / 13645579.2012 .756095}$

Carpentier, N. (2011). Media and participation: A site of ideological-democratic struggle. Bristol, UK: Intellect.

Castells, M. (2008). The New Public Sphere: Global Civil Society, Communication Networks, and Global Governance. ANNALS, AAPSS, 616, 78-93. DOI: https://doi. org/10.1177/0002716207311877

Coleman, S., \& Blumler, J. G. (2009). The Internet and democratic citizenship: Theory, practice and policy. Cambridge, MA: Cambridge University Press.

Chadwick, A. (2013). The bybrid media system: Politics and power. New York, NY: Oxford University Press.

Dahlgren, P. (2005). The Internet, public spheres, and political communication: Dispersion and deliberation. PoliticalCommunication, 22(2), 147-162.DOI: https://doi.org/10.1080/10584600590933160

Deuze, M. (2003). The web and its journalisms: considering the consequences of different types of newsmedia online. New Media \& Society, 5(2), 203-230. DOI: https://doi. org/10.1177/1461444803005002004 
D’heer, E., \& Verdegem, P. (2014). Conversations about the elections on Twitter: Towards a structural understanding of Twitter's relation with the political and the media field. European Journal of Communication, 29(6), 720-734. DOI: https://doi.org/10.1177/0267323114544866

Dubois, E., \& Blank, G. (2018). The echo chamber is overstated: the moderating effect of political interest and diverse media. Information, Communication \& Society, 21(5), 729-745. DOI: https://doi.org/10.1080/1369118X.2018.1428656

Esteve, M., \& Borge, R. (2018). Echo Chambers in Parliamentary Twitter Networks: The Catalan Case. International Journal of Communication 12, 1715-1735. DOI: https://doi.org/1932$\underline{8036 / 20180005}$

Europa Press (2015, November 25). ¿Quiénes son los periodistas más influyentes para nuestros políticos? Retrieved from http://www.europapress.es/portaltic/socialmedia/noticia-quienes-son periodistas mas-influyentes-politicos-20150521191145.html

Ferree, M. M., Gamson, W. A., Gerhards, J., \& Rucht, D. (2002). Four Models of the Public Sphere in Modern Democracies. Theory and Society, 31(3), 289-324. DOI: https://doi. org/10.1023/A:1016284431021

Freelon, D., \& Karpf, D. (2015). Of Big Birds and bayonets: Hybrid Twitter interactivity in the 2012 presidential debates. Information, Communication \& Society, 18(4), 390-406. DOI: https://doi. $\underline{\operatorname{org} / 10.1080 / 1369118 X .2014 .952659}$

Giglietto, F., \& Selva, D. (2014). Second screen and participation: a content analysis on a full season dataset of tweets. Journal of Communication, 64(2), 260-277. DOI: https://doi.org/10.1111/ jcom.12085

Gil de Zúñiga, H., García-Perdomo, V., \& McGregor, S. C. (2015). What is second screening? Exploring motivations of second screen use and its effects on online political participation. Journal of Communication, 65(5), 793-815. DOI: https://doi.org/10.1111/jcom.12174

Graham, T., Broersma, M., Hazelhoff, K., \& Van’t Haar, G. (2013). Between broadcasting political messages and interacting with voters. The use of Twitter during the $2010 \mathrm{UK}$ general election campaign. Information, Communication \& Society, 16(5), 692-716. DOI: https://doi.org/10.1 $\underline{080 / 1369118 X .2013 .785581}$ 
Graham, T., Jackson, D., \& Broersma, M. (2016). New platform, old habits? Candidates' use of Twitter during the 2010 British and Dutch general elections campaigns. New Media \& Society, 18(5), 765-783. DOI: https://doi.org/10.1177/1461444814546728

Guo, Lei, Rohde, Jacob A., \& Wu, H. Denis (2018). Who is responsible for Twitter's echo chamber problem? Evidence from 2016 U.S. election networks. Information, Communication \& Society, 21(12). DOI: https://doi.org/10.1080/1369118X.2018.1499793

Hosch-Dayican, B., Amrit, C., Aarts, K., \& Dassen, A. (2016). How do online citizens persuade fellow voters? Using Twitter during the 2012 Dutch Parliamentary Election campaign. Social Science Computer Review, 34(2), 135-152. DOI: https://doi.org/10.1177/0894439314558200

Honeycutt, C., \& Herring, S. C. (2009). Beyond microblogging: Conversation and collaboration via Twitter. In HICSS '09: Proceedings of the 42nd Hawaii International Conference on System Sciences (pp. 1-10). Washington: IEEE Computer Society.

Humphreys, L., Gill, P., Krishnamurthy, B., \& Newbury, E. (2013). Historizing New Media: A Content Analysis of Twitter. Journal of Communication, 63(3), 413-431. DOI: https://doi. org/10.1111/jcom.12030

Jenkins, H., Allen, D., Bailey, M., Carpentier, N., Fenton, N., Lothian, A., Qiu, J. L., Schäfer, M. T., \& Srinivasan, R. (2014). Participations: Dialogues on the Participatory Promise of Contemporary Culture and Politics. Forum. International Journal of Communication, 8, 1129-1151. DOI: https://doi.org/1932-8036/2014FRM0002

Jenkins, H., Ford, S., \& Green, J. (2013). Spreadable Media: Creating Value and Meaning in a Networked Culture. New York: NYU Press.

Jungherr, A. (2014). The logic of political coverage on Twitter: Temporal dynamics and content. Journal of Communication, 64(2), 239-259. DOI: https://doi.org/10.1111/jcom.12087

Jungherr, A., Schoen, H., \& Jürgens, P. (2015). The Mediation of Politics through Twitter: An Analysis of Messages posted during the Campaign for the German Federal Election 2013. Journal of Computer-Mediated Communication, 21, 50-68. DOI: https://doi.org/10.1111/jcc4.12143 
Karlsson, M., Bergström, A., Clerwall, C., \& Fast, K. (2015). Participatory journalism - the (r) evolution that wasn't. Content and user behavior in Sweden 2007-2013. Journal of ComputerMediated Communication, 20, 295-311. DOI: https://doi.org/10.1111/jcc4.12115

Kwak, H., Lee, C., Park, H., \& Moon, S. (2010). What is Twitter, a social network or a news media? In WWW'10: Proceedings of the 19th international conference on the world wide web (pp. 591-600). New York: ACM.

Larsson, A. O. (2014). Everyday elites, citizens, or extremists? Assessing the use and users of non-election political hashtags. MedieKultur - Journal of media and communication research, 56, 6178. DOI: https://doi.org/10.7146/mediekultur.v30i56.8951

Larsson, A. O., \& Ihlen, O. (2015). Birds of a feather flock together? Party leaders on Twitter during the 2013 Norwegian elections. European Journal of Communication, 30(6), 666-681. DOI: https://doi.org/10.1177/0267323115595525

Larsson, A. O., \& Moe, H. (2011). Studying political microblogging: Twitter users in the 2010 Swedish election campaign. New Media \& Society, 14(5), 729-747. DOI: https://doi. org/10.1177/1461444811422894

Larsson, A. O., \& Moe, H. (2013). Representation or Participation? 'Twitter use during the 2011 Danish Election Campaign. Javnost - The Public, 20(1), 71-88. DOI: https://doi.org/10.1080/131 $\underline{83222.2013 .11009109}$

Larsson, A. O., \& Moe, H. (2014). Triumph of the Underdogs? Comparing Twitter Use by Political Actors During Two Norwegian Election Campaigns. SAGE Open, October-December, 1-13. DOI: $\underline{\text { https://doi.org/10.1177/2158244014559015 }}$

Lecheler, S., \& Kruikemeier, S. (2016). Re-evaluating journalistic routines in a digital age: a review of research on the use of online sources. New Media \& Society, 18(1), 156-171. DOI: https://doi.org/10.1177/1461444815600412

Limia, M., López, X., \& Toural, C. (2016). La interactividad y la conversación como motor de la innovación. In C. Sádaba, J. A. García Avilés, \& M. P. Martínez-Costa (Coords.), Innovación y desarrollo de los cibermedios en España (pp. 49-60). Pamplona: Eunsa. 
Maireder, A., Weeks, B. E., Gil de Zúñiga, H., \& Schlögl, S. (2015). Big Data and Political Social Networks: Introducing Audience Diversity and Communication Connector Bridging Measures in Social Network Theory. Social Science Computer Review, 1-16. DOI: https://doi. $\operatorname{org} / 10.1177 / 0894439315617262$

Messner, M., Linke, M., \& Eford, A. (2011, April). Shoveling tweets: an analysis of the microblogging engagements of traditional news organizations. Paper presented at the 11th International Symposium on Online Journalism, Austin, TX. Retrieved from https://online.journalism.utexas.edu/2011/ papers/Messner2011.pdf

Molyneux, L. (2015). What journalists retweet: Opinion, humor, and brand development on Twitter. Journalism, 6(7), 920-935. DOI: https://doi.org/10.1177/1464884914550135

Moon, S. J., \& Hadley, P. (2014). Routinizing a New Technology in the Newsroom: Twitter as a News Source in Mainstream Media. Journal of Broadcasting \& Electronic Media, 58(2), 289-305. DOI:_https://doi.org/10.1080/08838151.2014.906435

Papacharissi, Z., \& De Fatima Oliveira, M. (2012). Affective news and networked publics: the rhythms of news storytelling on \#Egypt. Journal of Communication, 62(2), 266-282. DOI: https:// doi.org/10.1111/j.1460-2466.2012.01630.x

Paulussen, S., Heinonen, A., Domingo, D., \& Quandt, T. (2007). Doing it Together: Citizen Participation in the Professional News Making Process. Observatorio (OBS*) Journal, 3, 131-154. DOI: https://doi.org/1646-5954/ERC123483/2007

Park, C. S. (2013). Does Twitter motivate involvement in politics? Tweeting, opinion leadership, and political engagement. Computers in Human Behavior, 29(4), 1641-1648. DOI: https://doi. org/10.1016/j.chb.2013.01.044

Parmelee, J. H. (2014). The agenda-building function of political tweets. New Media \& Society, 16(3), 434-450. DOI: https://doi.org/10.1177/1461444813487955

Rauchfleisch, A., \& Metag, J. (2016). The special case of Switzerland: Swiss politicians on Twitter. New Media \& Society, 18(10), 2413-2431. DOI: https://doi.org/10.1177/1461444815586982

Tumasjan, A., Sprenger, T. O., Sandner, P. G., \& Welpe, I. M. (2010). Predicting elections 
with Twitter: What 140 characters reveal about political sentiment. In Proceedings of the Fourth International AAAI Conference on Weblogs and Social Media (pp. 178-185). Menlo Park, CA: The AAAI Press.

Vaccari, C., Chadwick, A., \& O’Loughlin, B. (2015). Dual Screening the Political: Media Events, Social Media, and Citizen Engagement. Journal of Communication, 65, 1041-1061. DOI: https:// doi.org/10.1111/jcom.12187

Vaccari, C., \& Valeriani, A. (2015). Follow the leader! Direct and indirect flows of political communication during the 2013 Italian general election campaign. New Media \& Society, 17(7), 1025-1042. DOI: https://doi.org/10.1177/1461444813511038

Wallsten, K. (2015). Non-elite Twitter sources rarely cited in coverage. Newspaper Research Journal, 36(1), 24-40. DOI: https://doi.org/10.1177/0739532915580311 
MHCJ no 10 (1) | Año 2019 - Artículo no 6 (141) - Páginas 123 a 145 - mhjournal.org

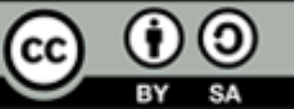

Licencia Creative Commons

Miguel Hernández Communication Journal

mhjournal.org

\section{Cómo citar este texto:}

Silvia Blas Riesgo, Elsa Moreno Moreno, Idoia Portilla (2019): Live political events on Twitter: The case of the 2015 Election Night in Spain, in Miguel Hernández Communication Journal, nº10 (1), pp. 123 a 145. Universidad Miguel Hernández, UMH (Elche-Alicante). DOI: http://dx.doi.org/10.21134/mhcj.v10i0.281 